\title{
TUNNEL SUPPORT DESIGN BY COMPARISON OF EMPIRICAL AND FINITE ELEMENT ANALYSIS OF THE NAHAKKI TUNNEL IN MOHMAND AGENCY, PAKISTAN
}

\author{
ASIF RIAZ, SYED MUHAMMAD JAMIL \\ National University of Sciences and Technology, Pakistan (NUST) \\ MUHAMMAD ASIF, KAMRAN AKHTAR \\ NUST Institute of Civil Engineering (NICE)
}

\begin{abstract}
The paper analyses the geological conditions of study area, rock mass strength parameters with suitable support structure propositions for the under construction Nahakki tunnel in Mohmand Agency. Geology of study area varies from mica schist to graphitic marble/phyllite to schist. The tunnel ground is classified and divided by the empisical classification systems like Rock mass rating (RMR), Q system (Q), and Geological strength index (GSI). Tunnel support measures are selected based on RMR and Q classification systems. Computer based finite element analysis (FEM) has given yet another dimension to design approach. FEM software Phase 2 version 7.017 is used to calculate and compare deformations and stress concentrations around the tunnel, analyze interaction of support systems with excavated rock masses and verify and check the validity of empirically determined excavation and support systems.
\end{abstract}

Key words: rock mass strength parameters, rock mass classification, FEM analysis, Phase2, tunnel support design

\section{INTRODUCTION}

The aim of this research is to analyze the geological parameters of the rock mass and to obtain rock mass strength parameters, finally suggesting tunnel support measures of the under construction Nahakki Tunnel situated on the road Ghalanai-Mohmand gat from RD $15+010$ at El. $827.00 \mathrm{~m}$ and RD $15+670$ at El. $820.00 \mathrm{~m}$ in Mohmand Agency (Fig. 1).

Mohmand Agency is situated in a complicated terrain at the foothills of Himalayas. Geologically, the Mohmand Agency comprises Paleozoic rocks, largely unclassified. A great variety of metamorphic rocks is exposed in the region ranging from mica schist, schists and phyllites to quartzite and marbles (Technical feasibility report Nahakki road tunnelNESPAK; National Engineering services Pakistan private limited).

The Tunnel is situated $10 \mathrm{~km}$ north of Ghalanai, on the road Ghalanai-Mohmand gat in northern Pakistan. Frontier Works Organization (FWO) is main contractor with NESPAK as consultant/designer. Nahakki Tunnel is a D shaped single tube bi-directional two lane road tunnel. Currently, the tunnel is under construction and it has achieved excavation of 400 meters approximately out of the total 660 meters. The Tunnel is 10.50 meters wide with semicircular roof arch of 5.1 meter radius resting on 3 meter high walls.

A detailed geological face mapping is being carried out during construction phase. To conclude the geotechnical properties of the surface/sub-surface rock mass along the tunnel alignment, field quantities (i.e., lithological documentation, determination of discontinuity characteristics, etc.), geological face mapping (determination of lithological units, rock discontinuities, rock quality designation (RQD) (Palmström [1]), joint conditions including roughness, persistency, aperture, weathering, etc.) were executed. The rock descriptions include both rock mass and rock material characteristics based on (Brown [5]). Additional geological face mapping practice was done for this research paper. The entrance section of Nahakki tunnel area is characterized by the presence of schists, dolomitic marble, quartzite and phyllites. It is observed during the site geological appraisal that the schist is predominant at the southern half of the proposed tunnel. Schist is very weak to moderately weak with moderately to highly weathering effect, 


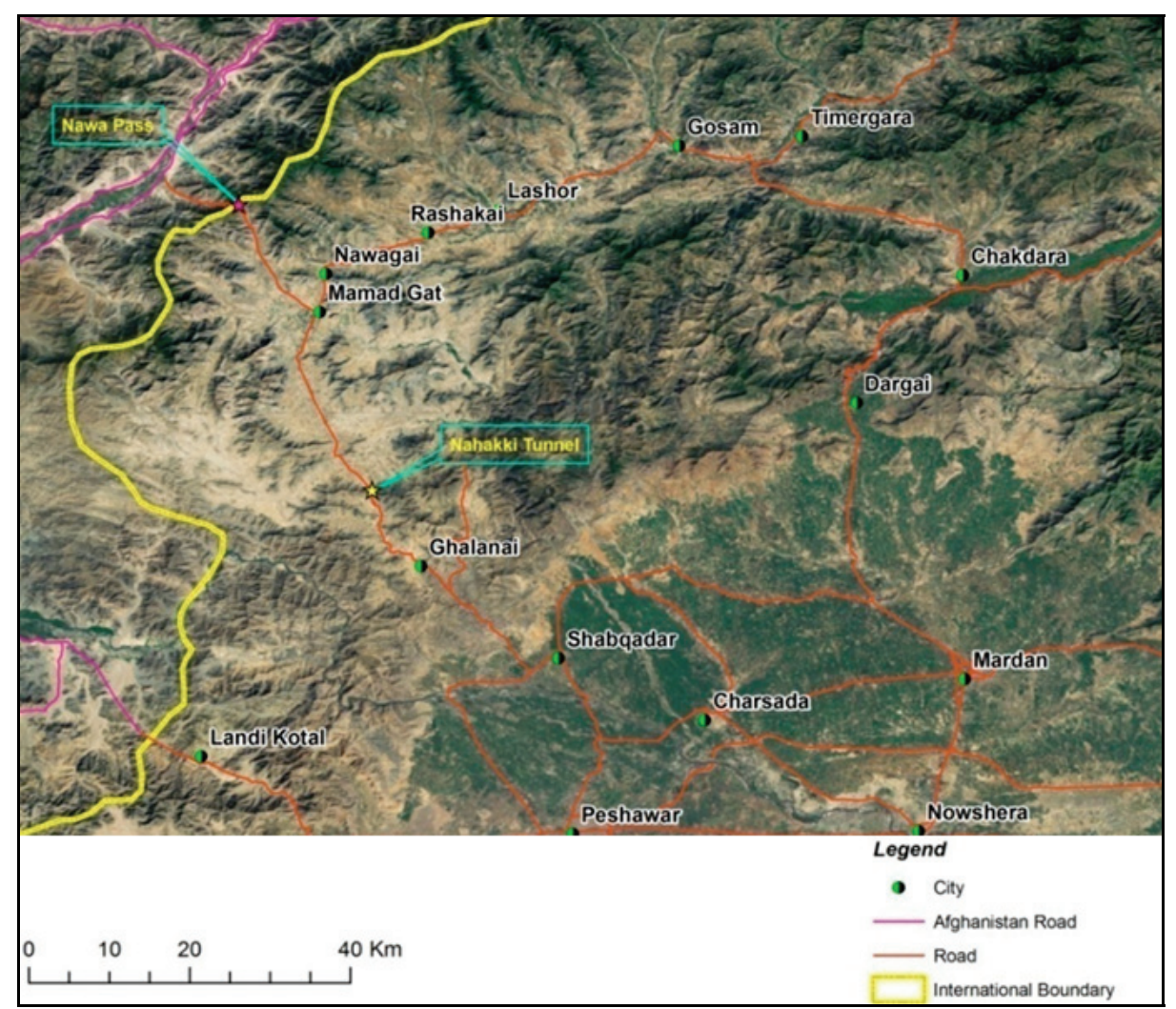

Fig. 1. Project location map

infrequently strong metamorphic rock. This formation is effortlessly disjointed along the foliation planes, with high persistency. The rocks across the proposed tunnel alignment are characterized by the presence of well developed, three to three plus random joint sets. The major controlling joint set is the one parallel to schistosity, which is generally dipping $40^{\circ}$ or more with an orientation in the space $290^{\circ}$ (Bieniawski [3]). Joint roughness forms important basis of the rock mass classification and also for the in-situ shear strength estimation of the joints. The joints particularly in the schists are smooth-planar with a few exceptions of smooth-undulating. Schist has 0.05 to $1.5 \mathrm{~m}$ average joint spacing. The geotechnical units in the northern half of the proposed tunnel are characterized by tight shear folding, which classify the joints mostly as smooth-undulating to occasionally rough-undulating. The joint walls as observed in the field are generally fresh and slightly to highly weathered. Subsurface water cannot be predicted with high certainty levels. It can be anticipated in view of the observations made for seepages during rainy season. However, as per the construction history of the tunnel, much less water had ingress into the tunnel during rains. The strikes of joints are perpendicular or nearly perpendicular to tunnel axis. Therefore, the locations of these discontinuities are evaluated as "favorable" (drive with the dip $20^{\circ}-45^{\circ}$ ) in accordance with tunnel excavation from southern side, and "fair" (drive against the dip $45^{\circ}-90^{\circ}$ ) in accordance with tunnel excavation from northern side (Bieniawski [3]).

\section{TUNNEL SUPPORT DESIGN BY EMPIRICAL ROCK MASS CLASSIFICATION}

The Tunnel is divided into five geological classes (GC-1 to GC-5) as shown in Fig. 2a according to the predominant geological strata as revealed in Fig. $2 b$ having geological section of tunnel alignment. RMR (Bieniawski [3]), Q system (Barton et al. [2]), and GSI (Sonmez and Ulusay [12]) rock mass classification system were used for rock mass classification and the tunnel support system was selected according to RMR and Q only. The rock mass classification (RMR, GSI and Q) is shown in Table 2, rock mass geomechanical properties as listed in Tables 1 and 3 are selected from physical face mapping (face mapping sheet of GC-5 is shown in Fig. 3) and the data bank of RocLab (RockLab [11]) based on the generalized Hoek-Brown failure criterion (Hoek et al. [4]) subsequently support system based on Q method is tabulated in Table 4. 


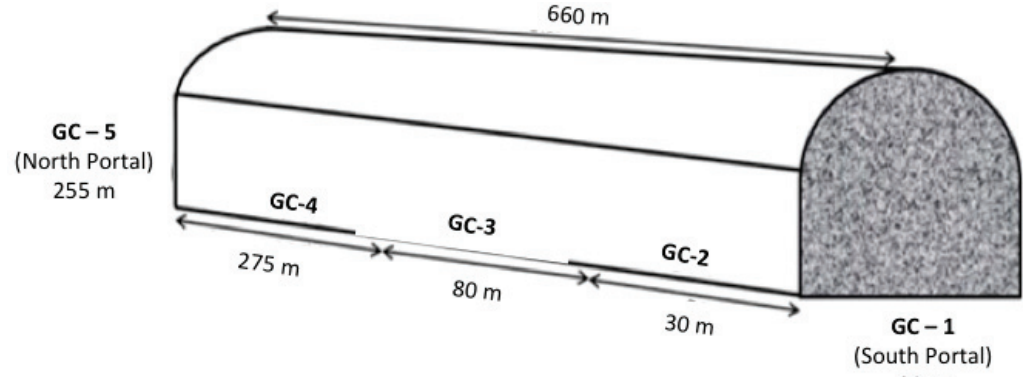

Fig. 2a. Schematic layout of tunnel with geological class division (not to scale)

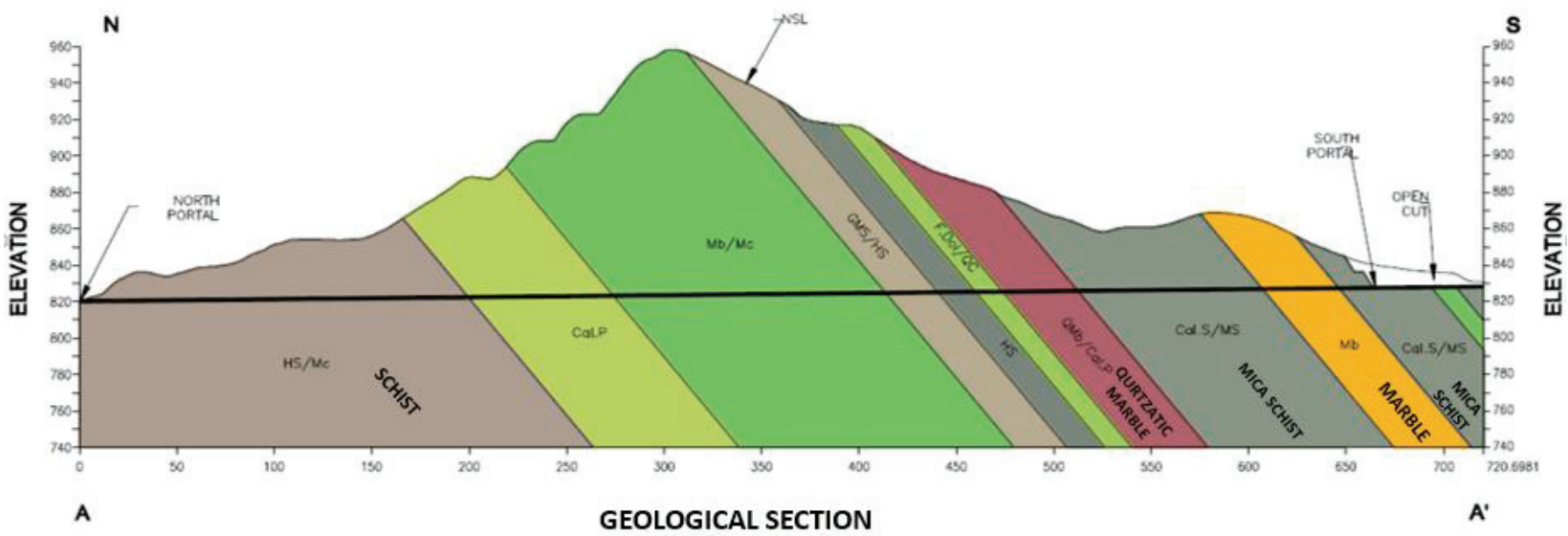

Fig. 2b. Geological section of tunnel alignment

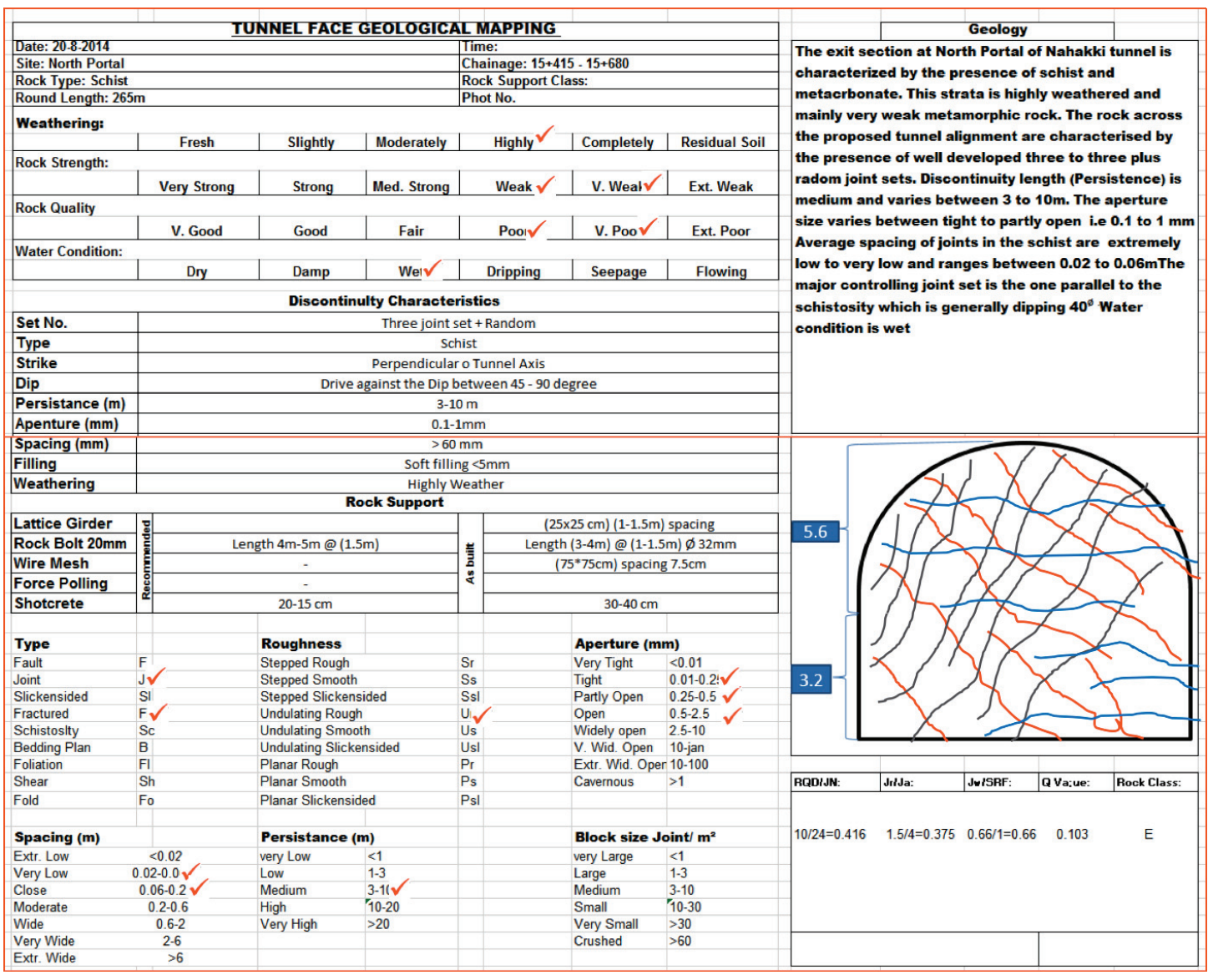

Fig. 3. Geological face mapping sheet for GC-5 
Table 1. Geological analysis data (rock mass/joint properties)

\begin{tabular}{|l|c|c|c|c|c|}
\hline \multicolumn{1}{|c|}{$\begin{array}{c}\text { Rock mass } \\
\text { Properties }\end{array}$} & GC1 & GC2 & GC3 & GC4 & GC 5 \\
\hline RQD & 16 & 21.5 & 43.5 & 19 & 10 \\
\hline UCS $\left(\sigma_{c}\right)(\mathrm{MPa})$ & 20 & 50 & 20 & 40 & 20 \\
\hline $\begin{array}{l}\text { Spacing of } \\
\text { discontinuities }\end{array}$ & $0.05-1.00 \mathrm{~m}$ & $0.05-1.00 \mathrm{~m}$ & $0.05-1.00 \mathrm{~m}$ & $0.05-2.00 \mathrm{~m}$ & $>60 \mathrm{~mm}$ \\
\hline Persistence $(\mathrm{m})$ & $1-3$ & $1-3$ & $1-3$ & $3-10$ & $3-10$ \\
\hline Aperture $(\mathrm{mm})$ & $0.1-1$ & $0.1-1$ & $0.1-1$ & $0.1-1$ & $0.1-1$ \\
\hline Roughness & $\begin{array}{c}\text { slightly } \\
\text { rough }\end{array}$ & $\begin{array}{c}\text { slightly } \\
\text { rough }\end{array}$ & $\begin{array}{c}\text { slightly } \\
\text { rough }\end{array}$ & rough & $\begin{array}{c}\text { slightly } \\
\text { rough }\end{array}$ \\
\hline Infilling & $\begin{array}{c}\text { hard filling } \\
<5 \mathrm{~mm}\end{array}$ & $\begin{array}{c}\text { hard filling } \\
<5 \mathrm{~mm}\end{array}$ & $\begin{array}{c}\text { hard filling } \\
<5 \mathrm{~mm}\end{array}$ & $\begin{array}{c}\text { hard filling } \\
>5 \mathrm{~mm}\end{array}$ & $\begin{array}{c}\text { soft filling } \\
<5 \mathrm{~mm}\end{array}$ \\
\hline Weathering & $\begin{array}{c}\text { moderately } \\
\text { weathered }\end{array}$ & $\begin{array}{c}\text { slightly } \\
\text { weathered }\end{array}$ & $\begin{array}{c}\text { slightly } \\
\text { weathered }\end{array}$ & $\begin{array}{c}\text { slightly } \\
\text { weathered }\end{array}$ & $\begin{array}{c}\text { highly } \\
\text { weathered }\end{array}$ \\
\hline $\begin{array}{l}\text { Groundwater } \\
\text { condition }\end{array}$ & dry & damp & damp & wet & wet \\
\hline $\begin{array}{l}\text { Discontinuity } \\
\text { orientation }\end{array}$ & favorable & favorable & favorable & favorable & fair \\
\hline $\begin{array}{l}\text { Joint set } \\
\text { number }\end{array}$ & 3 joint set & 3 joint set & $\begin{array}{c}2 \text { joint set } \\
\text { random }\end{array}$ & $\begin{array}{c}3 \text { joint set } \\
\text { + random }\end{array}$ & $\begin{array}{c}3 \text { joint set } \\
+ \text { random }\end{array}$ \\
\hline
\end{tabular}

Table 2. RMR, Q and GSI values along Nahakki Tunnel

\begin{tabular}{|l|c|c|c|c|}
\hline \multicolumn{1}{|c|}{ Geological class $(\mathrm{GC})$} & Lithology & RMR & Q & GSI \\
\hline $\begin{array}{l}\text { GC-1: } \\
\text { South portal }(20 \mathrm{~m})\end{array}$ & Mica schist & 46 & 0.425 & 38 \\
\hline GC-2 $(30 \mathrm{~m})$ & Marble & 43 & 1.183 & 40 \\
\hline GC-3 $(80 \mathrm{~m})$ & Mica schist & 48 & 1.435 & 42 \\
\hline GC-4 $(275 \mathrm{~m})$ & Quartzatic marble/phyllite & 33 & 0.392 & 32 \\
\hline $\begin{array}{l}\text { GC-5: } \\
\text { North portal }(255 \mathrm{~m})\end{array}$ & Schist & 23 & 0.103 & 26 \\
\hline
\end{tabular}

Table 3. Summary of geomechanical properties of rock mass sections along Nahakki Tunnel

\begin{tabular}{|c|c|c|c|c|c|c|c|c|c|c|c|c|}
\hline \multirow{2}{*}{$\begin{array}{l}\text { South } \\
\text { portal }\end{array}$} & \multicolumn{3}{|c|}{ Rock mass properties } & \multirow{2}{*}{ 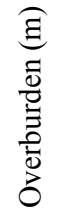 } & \multicolumn{2}{|c|}{$\begin{array}{l}\text { Hoek-Brown } \\
\text { parameters }\end{array}$} & \multicolumn{3}{|c|}{$\begin{array}{l}\text { Rock mass parameters } \\
\text { (undisturbed rock) }\end{array}$} & \multicolumn{3}{|c|}{$\begin{array}{l}\text { Rock mass parameters } \\
\text { (disturbed rock) }\end{array}$} \\
\hline & $\begin{array}{c}\sigma_{c} \\
(\mathrm{MPa})\end{array}$ & $\begin{array}{c}E_{i} \\
(\mathrm{MPa})\end{array}$ & $\begin{array}{c}\gamma \\
(\mathrm{MPa})\end{array}$ & & $m_{i}$ & $D$ & $\begin{array}{c}E_{m} \\
(\mathrm{MPa})\end{array}$ & $m$ & $s$ & $\begin{array}{c}E_{m} \\
(\mathrm{MPa})\end{array}$ & $m$ & $S$ \\
\hline GC-1 & 20 & 13500 & 0.026 & 35 & 15 & 0.6 & 1880 & 1.638 & 0.0010 & 802 & 0.634 & 0.0002 \\
\hline GC-2 & 50 & 42500 & 0.026 & 40 & 9.3 & 0.6 & 6785 & 1.091 & 0.0013 & 2838 & 0.436 & 0.0002 \\
\hline GC-3 & 20 & 13500 & 0.026 & 45 & 15 & 0.6 & 2470 & 1.89 & 0.0016 & 1018 & 0.778 & 0.0003 \\
\hline GC-4 & 40 & 22000 & 0.026 & 50 & 13 & 0.6 & 2040 & 1.146 & 0.0005 & 1172 & 0.405 & 0.0001 \\
\hline GC-5 & 20 & 13500 & 0.026 & 40 & 12 & 0.4 & 857 & 0.854 & 0.0003 & 547 & 0.441 & 0.00007 \\
\hline
\end{tabular}

Table 4. Summary of support systems of Nahakki Tunnel according to Q System

\begin{tabular}{|c|c|c|c|c|c|c|}
\hline \multicolumn{2}{|c|}{ Support systems } & GC-1 & GC-2 & GC-3 & GC-4 & GC-5 \\
\hline \multicolumn{2}{|c|}{\begin{tabular}{|l} 
Q Value \\
\end{tabular}} & 0.46 & 1.18 & 1.44 & 0.39 & 0.10 \\
\hline \multicolumn{2}{|c|}{ Rock class } & $\mathrm{E}$ & $\mathrm{D}$ & $\mathrm{D}$ & $E$ & $E$ \\
\hline \multicolumn{2}{|c|}{ Support cat } & 27 & 23 & 23 & 31 & 32 \\
\hline \multirow{3}{*}{$\begin{array}{l}\frac{y}{0}= \\
\propto 2 \\
\simeq\end{array}$} & Dia (mm) & 20 & 20 & 20 & 20 & 20 \\
\hline & Spacing $(\mathrm{m})$ & 1 & $1-1.5$ & $1-1.5$ & 1 & 1 \\
\hline & Length (m) & 4 & 4 & 4 & 4 & 4 \\
\hline \multicolumn{2}{|c|}{ Shotcrete $(\mathrm{cm})$} & $7.5-10$ & $5-10$ & $5-10$ & $5-12.5$ & $20-40$ \\
\hline \multicolumn{2}{|c|}{\begin{tabular}{|l|} 
Unsupported \\
span $(\mathrm{m})$
\end{tabular}} & 1.42 & 2.2 & 2.3 & 1.4 & 0.8 \\
\hline
\end{tabular}




\section{VERIFICATION OF TUNNEL SUPPORT BY FINITE ELEMENT MODELING SOFTWARE PHASE2}

The aim of the finite element method analysis is to verify the empirically (Nghia and Kristina [7]) evaluated tunnel support design given in Table 4. For this purpose, the FEM software module Phase 2 was applied to evaluate induced stresses and maximum deformation for excavated portion of the tunnel and to examine the proposed tunnel support. Excavation section will be D shaped $12 \mathrm{~m} \times 8.5 \mathrm{~m}$. Complete tunnel has been divided into sections according to the rock mass geotechnical properties assessed through geological face mapping. Q system classifies the tunnel with dominating $\mathrm{E}$ class, i.e., very poor (Barton et al. [2]) towards North portal. Class E is also expected to be faced for weak zone of mica schist. The Tunnel was divided into five geological classes (GC-1 to GC-5) to be used as Phase 2 models to compute and interpret the stresses and deformations leading to proposed support elements. The worst geological conditions are encountered by GC-5 as a result of $\mathrm{Q}$ classification shown in Table 4 and geological face mapping of GC-5 is shown in Fig. 3. For this paper, numerical analysis is performed only for the worst geological portion, i.e., GC-5. Actual dimensions of the tunnel opening are drawn in Autodesk and then imported into Phase 2 as excavation opening. Finite element mesh is built around the opening with extension factor as per requirement. For Nahakki tunnel, excavation opening with finite element mesh is shown in Fig. 4.

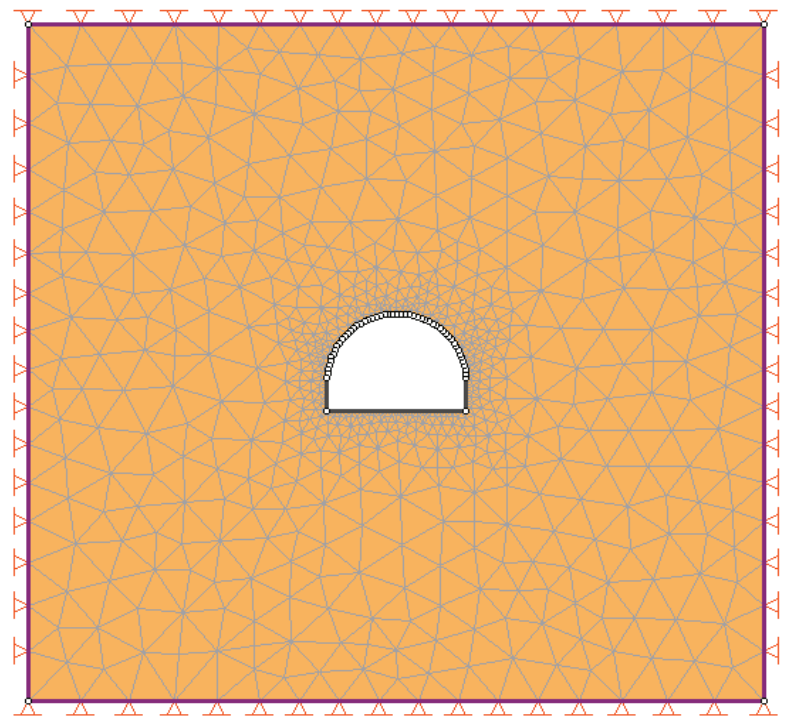

Fig. 4. Excavation section modeled in finite element mesh
Stresses in field conclude the preliminary conditions of in-situ stress as pre excavation state. As a practice, $\sigma_{1}$ and $\sigma_{3}$ are taken as in plane in-situ major and minor principal field stresses, respectively, and $\sigma_{2}$ as out of plane stress. At Nahakki tunnel, $\sigma_{1}$ and $\sigma_{3}$ are acting in horizontal direction. Vertical stresses have been calculated related to the depth below the surface and unit weight of the rock. Plate tectonic movements, which produce tectonic stresses, generate horizontal stresses, and these can be much higher than vertical stresses. This anisotropy in the stress field is represented by initial stress ratio $K\left(\sigma_{h}=K \sigma_{v}\right)$. Two dimensional tunnel modeling is assumed to have in-situ stress ratio $(k)$ near to unity, so as to achieve stable tunnel closure at the end of model (Vlachopoulos and Diederichs [13]), however, for this paper value for in-situ stress ratio has been taken from the stress ratio chart formulated by Hoek and Brown in 1978. Calculation of in-situ field stresses for this study has been shown in Table 5. Snap window as shown in Fig. 5 reflects the input stresses used for finite element modeling.

Table 5. Field stresses

\begin{tabular}{|c|c|c|c|c|c|c|}
\hline Section & $\begin{array}{c}\text { Overburden } \\
Z(\mathrm{~m})\end{array}$ & $\begin{array}{c}\gamma \\
(\mathrm{MPa})\end{array}$ & $\begin{array}{c}\sigma_{v}\left(\sigma_{3}\right) \\
(\mathrm{MPa})\end{array}$ & $\begin{array}{c}K \\
(100 / \mathrm{Z}+0.3)\end{array}$ & $\begin{array}{c}\sigma_{h}\left(\sigma_{1}\right) \\
(\mathrm{MPa})\end{array}$ & $\begin{array}{c}\sigma_{2} \\
(\mathrm{MPa})\end{array}$ \\
\hline GC-1 & 35 & 0.026 & 0.91 & 3.16 & 2.87 & 2.35 \\
\hline GC-2 & 40 & 0.026 & 1.04 & 2.8 & 2.91 & 2.4 \\
\hline GC-3 & 45 & 0.026 & 1.17 & 2.52 & 2.95 & 2.45 \\
\hline GC-4 & 50 & 0.026 & 1.3 & 2.3 & 3 & 2.5 \\
\hline GC-5 & 40 & 0.026 & 1.04 & 2.8 & 2.91 & 2.4 \\
\hline
\end{tabular}

\begin{tabular}{|c|c|c|}
\hline Field Stress Properties & & \begin{tabular}{|l|l|}
8 & $x$ \\
\end{tabular} \\
\hline Field Stress Type: Constant & & $\mathrm{OK}$ \\
\hline Sigma 1 (MPa, Comp. +): & 291 & Cancel \\
\hline Sigma 3 (MPa, Comp. +): & 1.04 & \\
\hline Sigma Z (MPa, Comp. +): & 2.4 & \\
\hline Angle (degrees from horizontal, CCW): & 0 & \\
\hline Locked-in horizontal stress (in plane) ( $\mathrm{MPa}$, Comp. + ]): & 0 & \\
\hline Locked-in horizontal stress (out-of-plane] [MPa, Comp. +]: & 0 & Advanced $\gg$ \\
\hline
\end{tabular}

Fig. 5. In-situ field stresses input properties to software

In-situ stresses are taken as the category of constant loading for evaluation with average overburden height of 55 meters. The Hoek-Brown failure criterion was selected for FEM analysis (Hoek et al. [4]). The class $\mathrm{E}$ excavation is simulated through ten stages. Internal pressure equal to in-situ stresses was applied. Internal pressure factor 1 at Stage 1 means the magnitude of internal pressure will be the same as the field stress, while factor 0 means no load will be 
applied at that stage (Rocscience Inc. 2006). Other values of factor will be decreased gradually between stage 2 to stage 9 as shown in Fig. 6 and model at stage 1 will look as shown in Fig. 7.

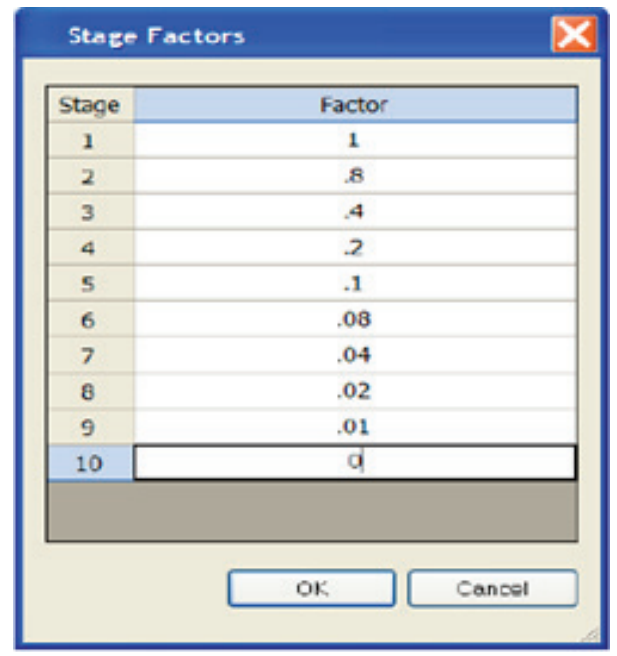

Fig. 6. Internal pressure stage factor
Phase2 computation engine will evaluate total displacement at each stage and maximum displacement will be at stage 10, as the internal pressure is zero. In this study, the maximum displacement was $0.101 \mathrm{~m}$ at stage 10 as shown in Fig. 8. The plot in Fig. 9 was created using the Vlachopoulos and Diederichs equations (Kersten [6]). Using this plot, it can easily estimate the amount of closure prior to support installation if the plastic radius and displacement far from the tunnel face are known.

To estimate the amount of closure prior to support installation, distance from the tunnel face is $1 \mathrm{~m}$. The radius of plastic zone $R_{\mathrm{pz}}$ is $19 \mathrm{~m}$, the tunnel radius $R_{\mathrm{t}}$ is $5.6 \mathrm{~m}$ (Fig. 9) and maximum displacement $u_{\max }=$ $0.101 \mathrm{~m}$ (Fig. 8).

The distance from tunnel face/tunnel radius $\left(D_{\mathrm{f}} / R_{\mathrm{t}}\right)$ $=1 / 5.6=0.178$. The plastic zone radius/tunnel radius $\left(R_{\mathrm{pz}} / R_{\mathrm{t}}\right)=19 / 5.6=3.39$. Figure 10 depicts maximum closure of 0.33 , here closure equals $C_{\mathrm{p}}=(0.33) *(0.101)$ $=0.033 \mathrm{~m}$ prior to support installation. This shows the tunnel displaces $0.033 \mathrm{~m}$ before the support is installed.

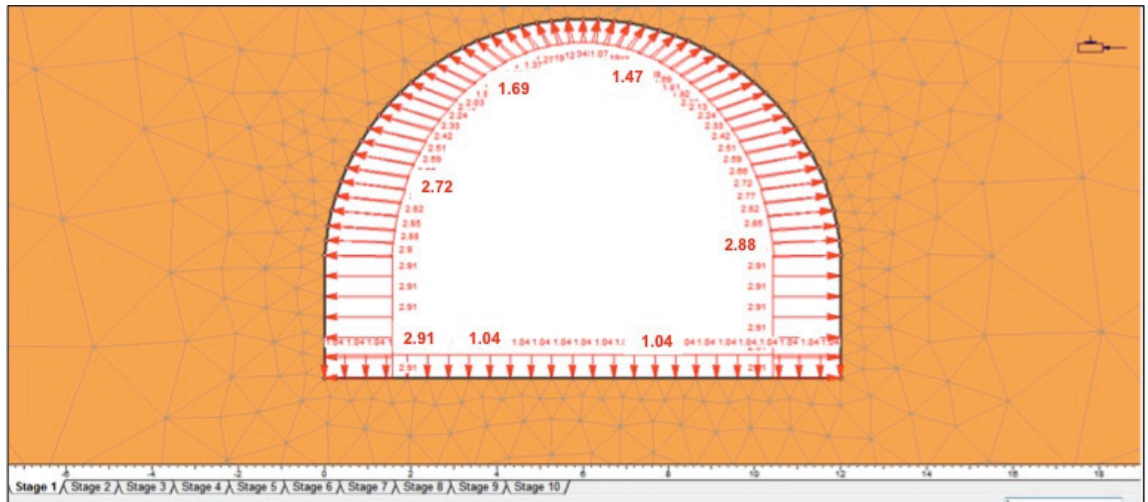

Fig. 7. Internal pressure distribution at stage 1

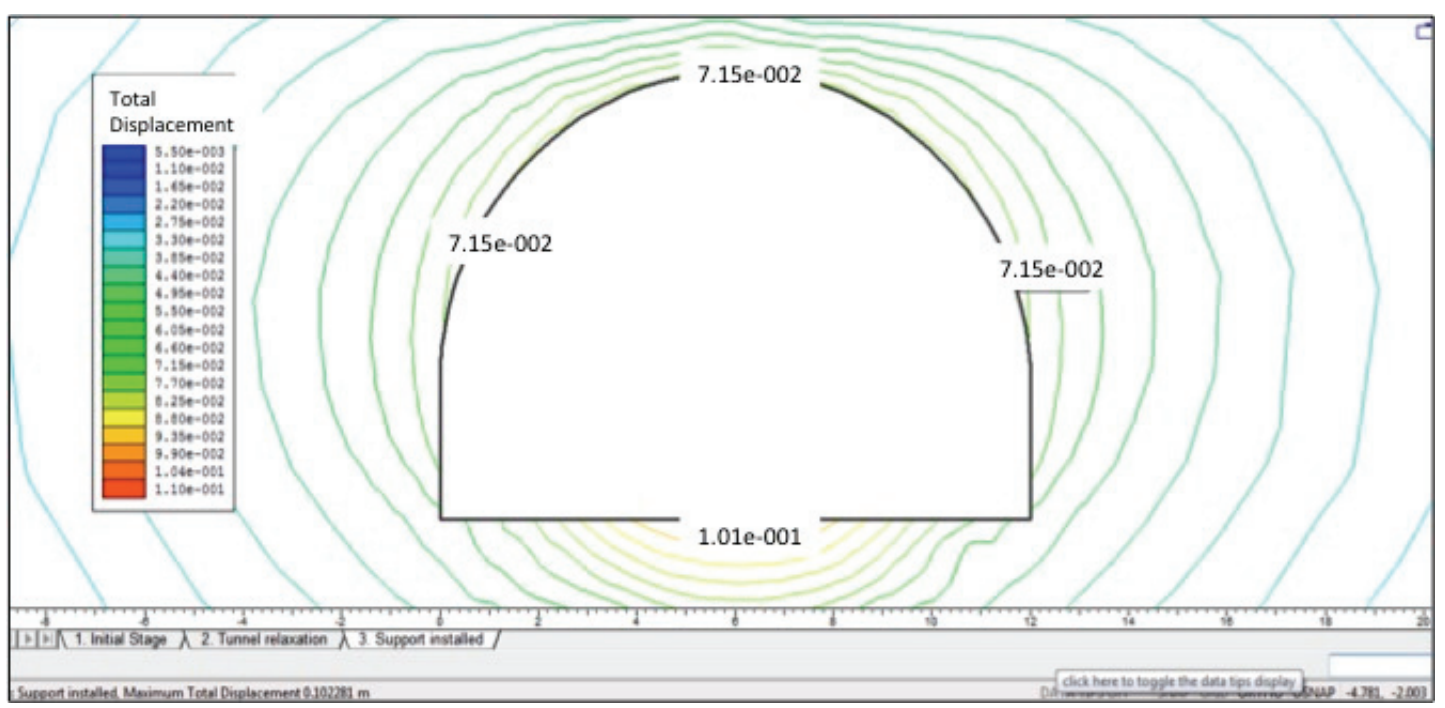

Fig. 8. Total displacements at the 10th stage 


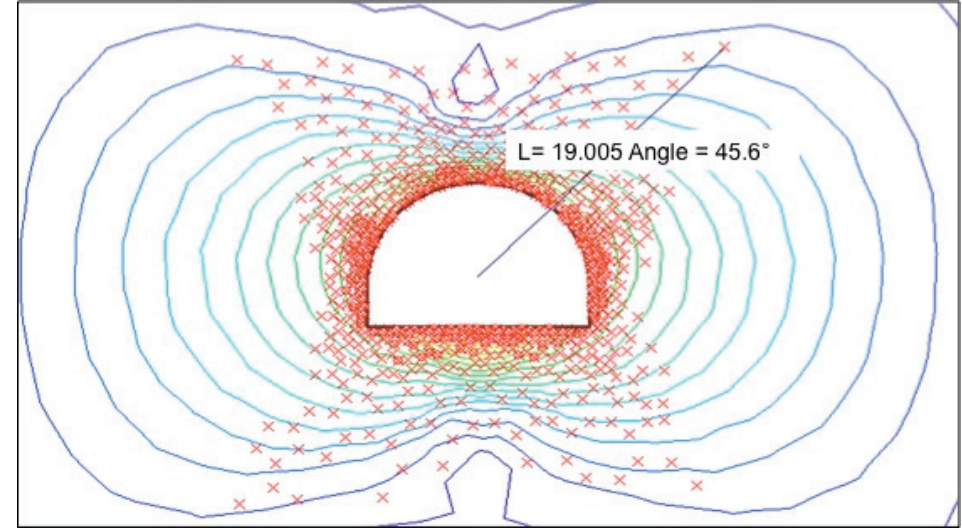

Fig. 9. Yielded zone (radius of plastic zone $R_{p z}-19 \mathrm{~m}$ )

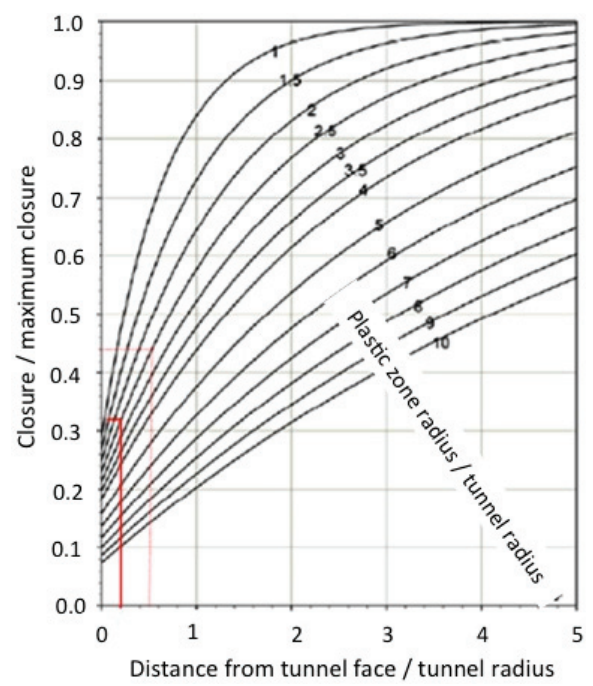

Fig. 10. Maximum closure of $0.33 \mathrm{~m}$

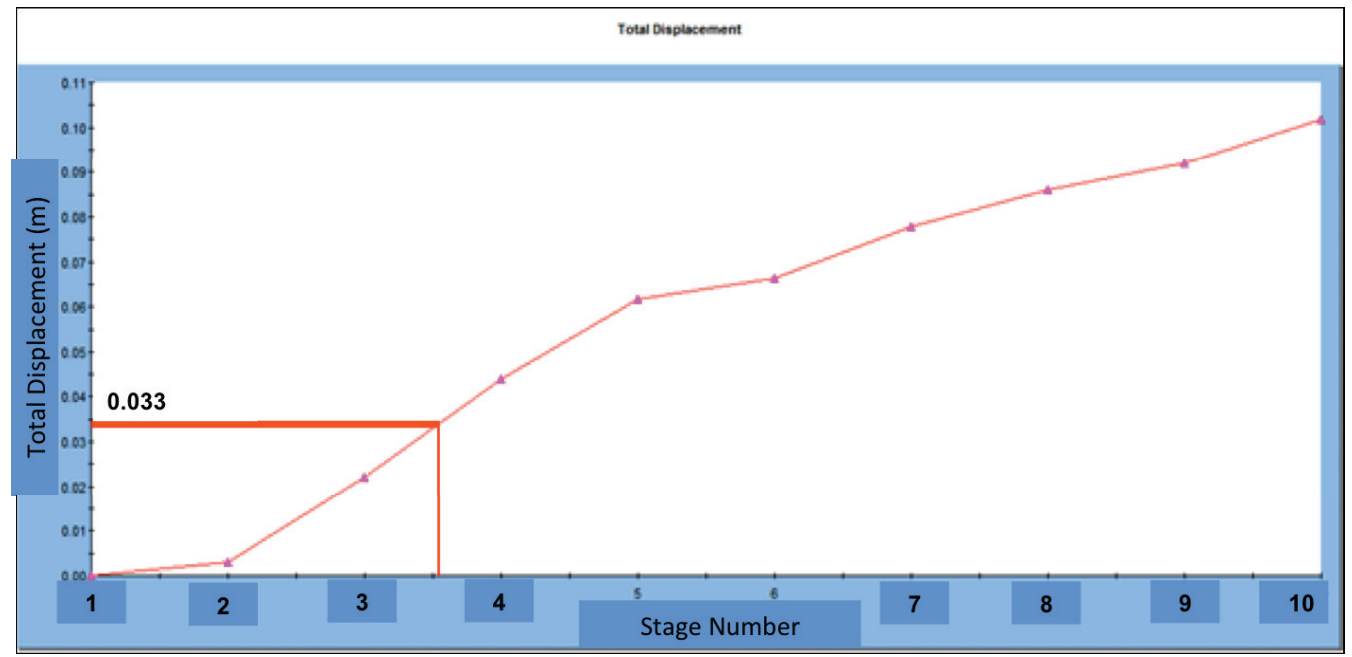

Fig. 11. Total displacement vs. stage number

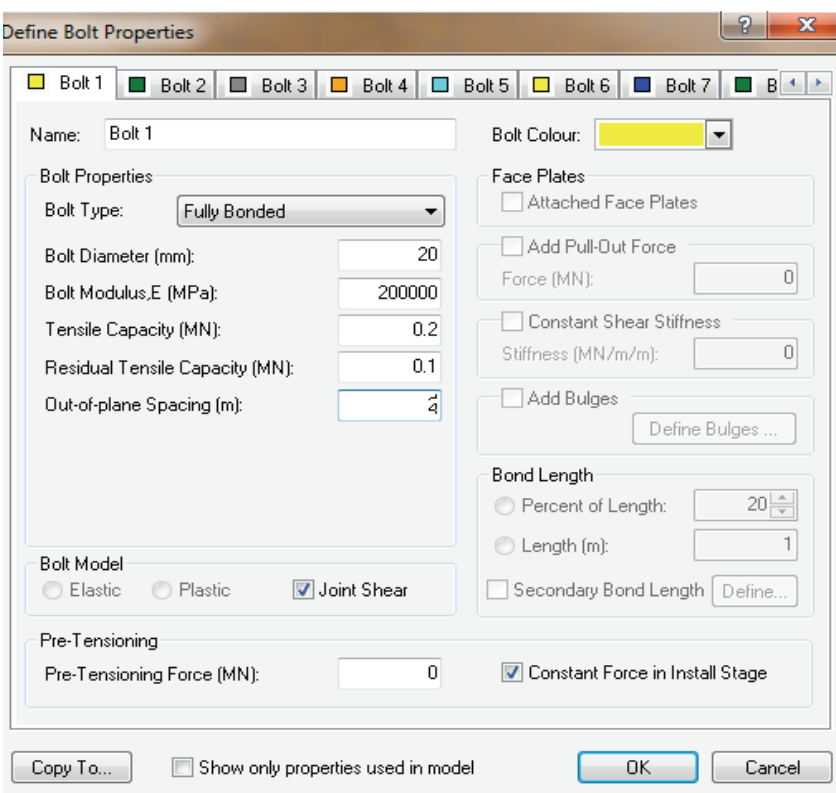

Fig. 12. Rock bolt properties
To determine the internal pressure that yields $0.033 \mathrm{~m}$ displacement, Fig. 11 shows the plot of displacement vs. stage excavation generated by the program. From this plot, at stage 4, the wall displacement is equal to $0.033 \mathrm{~m}$, therefore support will be installed at stage 4 .

Addition of rock bolts (4 meters in length each with grid spacing of $1 \times 1$ meter having load capacity of $0.2 \mathrm{MN}$ as illustrated in Fig. 12 depicting input rock bolt properties to Phase 2 model) normal to the boundary reduces displacement to $0.0638 \mathrm{~m}$ from $0.101 \mathrm{~m}$ is shown in Fig. 13.

To check the capacity of rock bolt, the maximum axial force on bolt \# 15 is $0.195 \mathrm{MN}$ as shown in Figs. 14 and 15 , which is very close to the capacity of rock bolt, i.e., $0.2 \mathrm{MN}$.

Next category in support element is shotcrete. Phase 2 takes this as liner with the properties of $30 \mathrm{~cm}$ thickness with peak compressive strength of $35 \mathrm{MPa}$ and Young's modulus of $30000 \mathrm{MPa}$. Snapshots 
of window showing shotcrete liner parameters for Phase2 input are shown in Fig. 16.

By adding liner of $30 \mathrm{~cm}$ thickness, the displacement is further reduced to $0.0578 \mathrm{~m}$ as shown in Fig. 17.

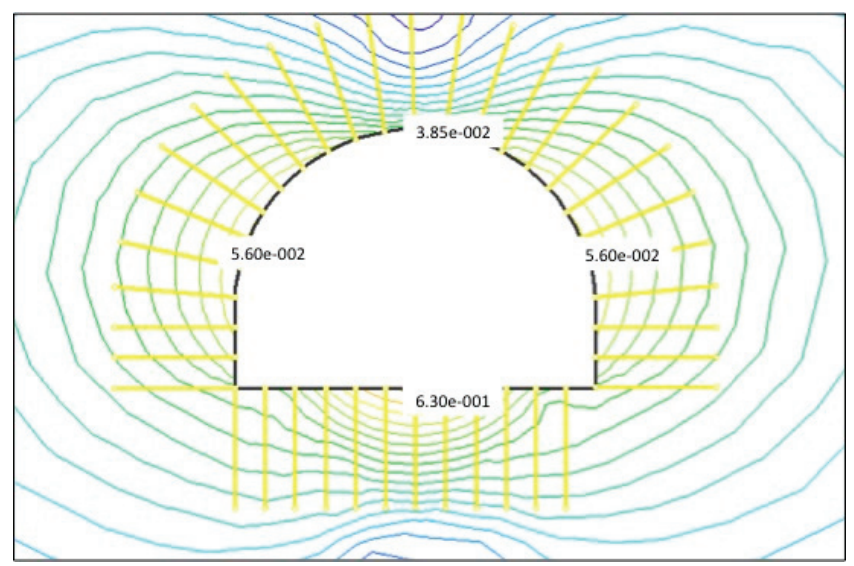

Fig. 13. Distribution of the maximum displacements $(0.0638 \mathrm{~m})$ with addition of rock bolts
Rock bolt number 33 is taking maximum axial force of $0.131 \mathrm{MN}$ at floor of the tunnel as shown in Fig. 18. It is evident that loads taken by support elements are well within the maximum capacity of rock bolt $(0.2 \mathrm{MN})$.

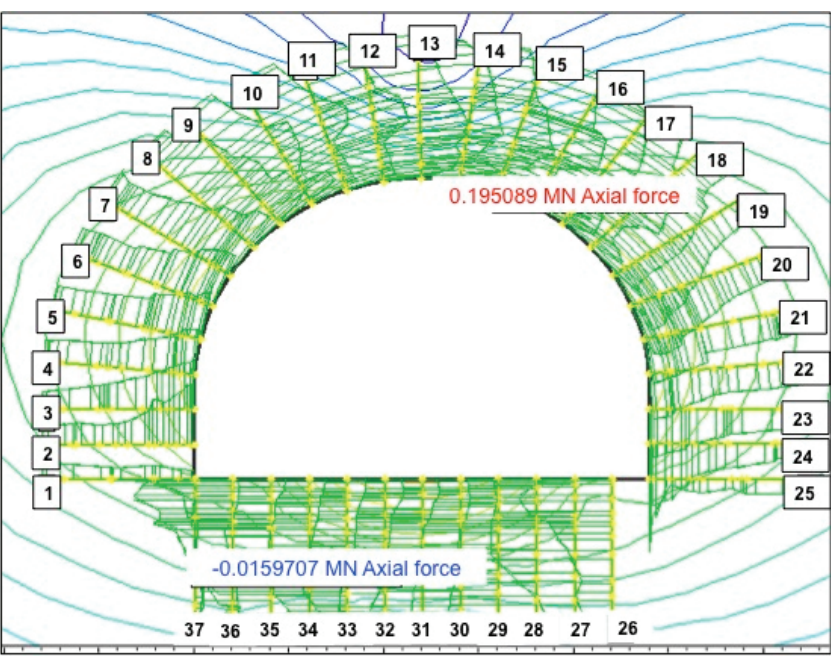

Fig. 14. Maximum and minimum axial force on rock bolt

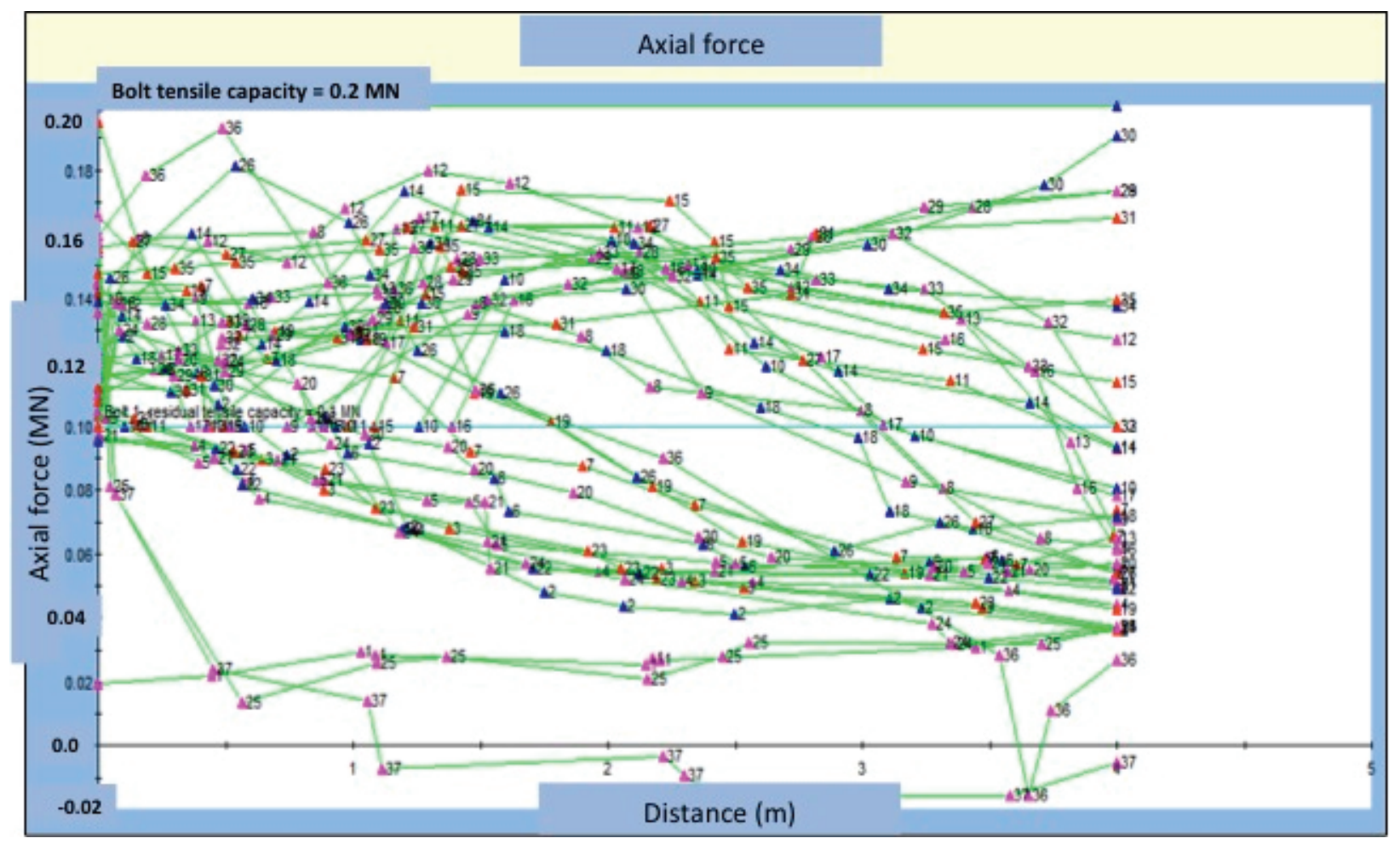

Fig. 15. Axial force on rock bolt with respect to its length inside rockmass 


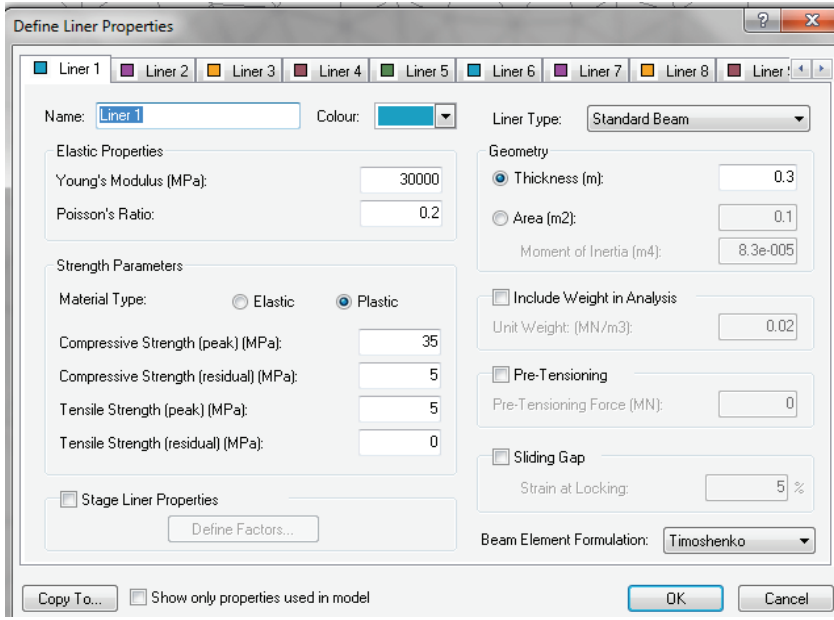

Fig. 16. Liner (shotcrete properties)

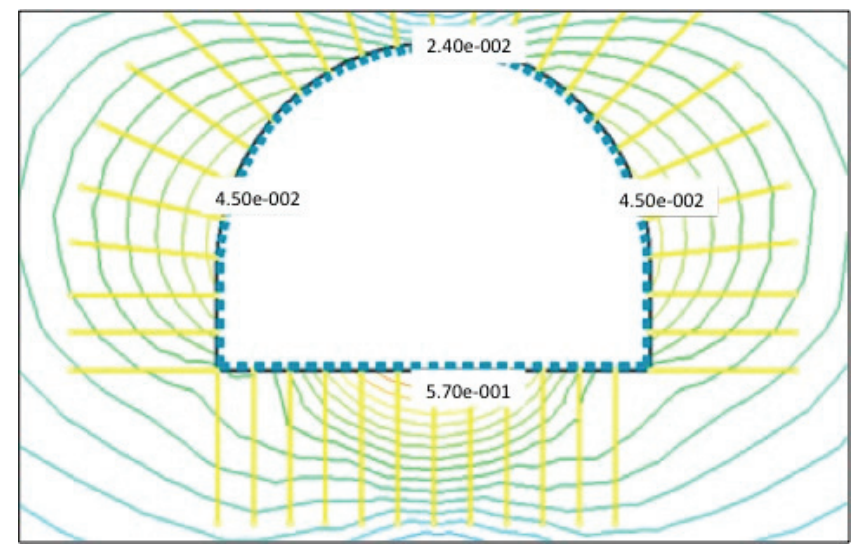

Fig. 17. Distribution of the maximum displacements $(0.0578 \mathrm{~m})$ with addition of shotcrete

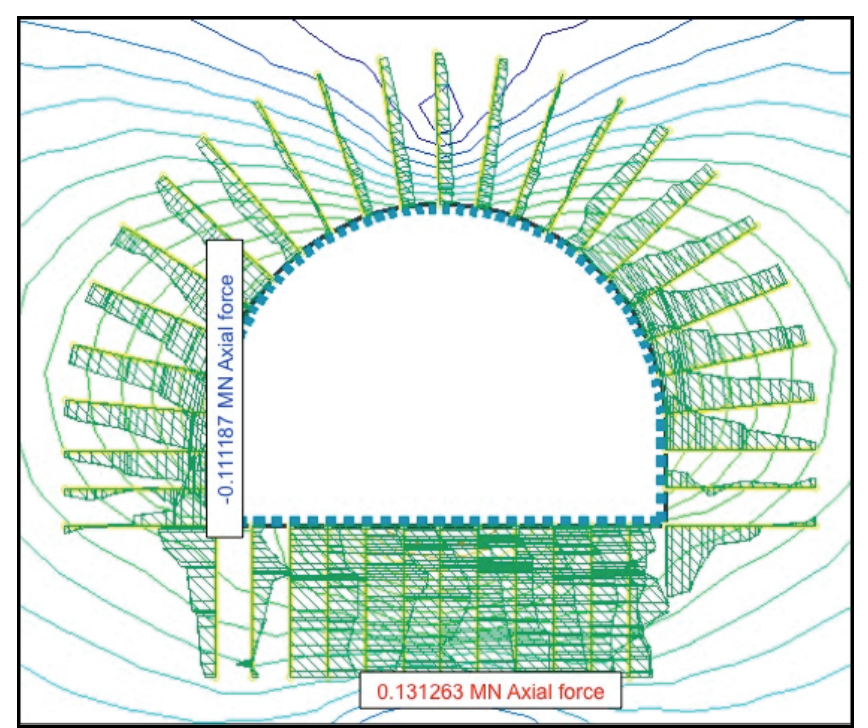

Fig. 18. Maximum and minimum axial force on rock bolt

\section{CONCLUSION}

This paper takes into account the geological characteristics of rock mass pitched with its geomechanical characteristics and suggests the suitable tunnel support systems. RMR, GSI and the Q rock mass classification systems were used. RocLab database was benefited to evaluate Hoek and Brown constants $m$ and $s$ and elastic modulus of rock masses. Five geological classes of Nahakki tunnel demonstrate poor to very poor quality rock mass. FEM software package, Phase2 is used to determine the induced stresses, deformations with proposal for support elements for the worst rock class E. Taking into consideration the geomechanical conditions of rock class E, load coming onto the excavated section and load carrying capacity of suggested support, it is determined that the suggested support for E Rock Class of Nahakki Tunnel is adequate.

\section{REFERENCES}

[1] Palmström A., Measurements of and correlations between block size and rock quality designation (RQD), Tunnels and Underground Space Technology, 2005, 20, 362-377.

[2] BARTON N., LIEN R., LUNDE J., Engineering classification of rock masses for the design of rock support, Rock Mechanics and Rock Engineering, 1974, 6(4), 189-236.

[3] BieniaWsKi Z.T., Engineering rock mass classifications, John Wiley \& Sons, 1989.

[4] Hoek E., Carranza-Torres C., Corkum B., Hoek-Brown failure criterion, 2002 Edition, Proceedings of NARMSTAC Conference, Toronto 2002.

[5] BROwn E.T., Rock Characterization, testing and monitoring: ISRM Suggested methods, E.T. Brown (ed.), Oxford: Pergamon Press, 1981.

[6] Kersten Lecture: Hoek E., CARranza-Torres C., Diederichs M.S., CORKUM B., Integration of geotechnical and structure design in tunneling. Proceedings University of Minnesota 56th Annual Geotechnical Engineering Conference, Minneapolis 2008.

[7] NAGHia T., KRISTINA J., Design consideration for an underground room in a hard rock subjected to a high horizontal stress field at Rana Gruber, Norway, Tunneling and Underground Space Technology, 2013, 38, 205-212.

[8] National Engineering Services Pakistan limited (NESPAK), Technical feasibility report Nahakki Road Tunnel 2013.

[9] Phase2, ver. 7.017, 2006, A two-dimensional elasto-plastic finite element program and its user's manual, by RocScience Inc, Toronto-Canada, 2006.

[10] Goodman R.E., Engineering geology: rock in engineering construction, John Wiley \& Sons, 1993.

[11] RocLab, ver. 1.031, 2007. A software program for determining rock mass strength parameters based on the generalized Hoek-Brown failure ctriterion, by RocScience Inc., Toronto-Canada 2007. 
[12] Sonmez H., Ulusay R., A discussion on the Hoek-Brown failure criterion and suggested modification to the criterion verified by slope stability case studies, Yerbilimleri (Earth Sciences), 2002, 26, 77-99.
[13] Vlachopoulos N., Diederichs M.S., Appropriate uses and limitations of $2 D$ numerical analysis of tunnels and tunnel support response, Geotechnical and Geological Engineering, 2014, Vol. 32, 2, 469-488. 